\title{
Policies Concerning Urban Safety and Urbanization in Istanbul
}

\author{
Mehmet Arican ${ }^{1 *}$ and Halil Ibrahim Bahar ${ }^{2}$ \\ ${ }^{1}$ Department of Criminal Justice \& Criminology, Sam Houston University, USA \\ ${ }^{2}$ Emeritus Professor of Sociology, Aksaray University, Turkey
}

Submission: March 20, 2020; Published: April 14, 2020

"Corresponding author: Mehmet Arican, Department of Criminal Justice, Sam Houston University, USA

\begin{abstract}
Taking Newman's “Defensible Space Theory into consideration, data presented in this article was collected by the International Strategic Research Organization as part of the four year, 2008 - 2012, Istanbul Urban Safety Project. Quantitative and qualitative methods were used in the study. Quantitative methods included a large questionnaire survey administered to two samples: households and workplaces; together with analysis of secondary data. The qualitative dimension comprised semi-structured, open-ended interviews with a number of senior officials involved in urban safety in Istanbul. This study argues that the state has abandoned its regulatory role within democratic urban politics; instead taking urbanization measures to further advantage the privileged elites at both a local and national level. Furthermore, it proposes that undemocratic urbanization policies are legitimised mainly on the basis of earthquake anxiety, together with some unsubstantiated issues such as security concerns, criminalization and marginalization.
\end{abstract}

Keywords:Istanbul; Urban regeneration; Inner city decay; Slum; Urban security

\section{Introduction}

Latterly Istanbul has been changing and 'developing' via transformative processes which are still continuing and show no sign of ending. Spatial separation in Istanbul has nurtured social, economic and political inequalities via the city's vertical segregation approach in which the elite live and work in exclusive office towers, housing blocks and shopping malls that are being constructed at an alarming rate. Istanbul presents a vivid and visually stunning example of how the rich lift themselves above the rest. This article argues that vertical segregation is yet one more strategy employed by elites to force the abandonment of public space.

The emergence of a new pattern of spatial segregation is justified by two developments. The first one is fear of earthquakes, with the second one arising from urban insecurity in Istanbul. This pattern of urban governance diverges significantly from Istanbul's historical experience, and rests upon new urban developments that have explicitly favoured the urban elites, both directly and indirectly. These raise critical questions about the nature of relations between social groups within the city.

Istanbul's global financial market share continues to grow to the point where it has become addictive, hence great swathes of the city are being rebuilt in the name of urbanization, rebuilding which is often justified on the grounds of 'fear of earthquakes' or 'security fears' thus circumventing normal democratic process. Even if the economy is not the main force in this redevelopment, its effect has been to erase much of Istanbul's history, geography, culture and urban social relationships. Urbanization policies have been enacted without sufficient consultation with local residents; hence the state-citizen relationship must be re-shaped, with the state justifying its sovereignty. The current very one-sided power relationship has the effect of objectifying citizens. In a totally legal fashion, low income groups are being forced out of city centers into urban margins, leaving the centers free for exploitation by the city's elite. Urbanization policies which have been implemented have not lived up to expectations, indeed, they could be said to have turned back the clock.

Mostly using qualitative data collection techniques and reviews, the literature on the issue of land occupation, migration, crime, urban area, regeneration and the relationship between urban space and crime in Istanbul is very extensive [1-5].

Urban regeneration is instrumentalized in the process of the poor, earthquake risks building stock and improving the 
conditions of disadvantaged neighbourhoods in Istanbul. The role of hegemonic state institutions in the realization of urban regeneration projects and centralisation of policy making power has been increasing [6]. Resulting in a growing pressure on squatter housing areas and the historic urban centres populated by the urban poor, there has been an increase in the importance of urban areas that have high rent-gaining potential [7-9]. Examining the relations between new economic policy, new urban policy and urban development projects, Sakızoğlu [10] argues that urban renewal plans shaped by the municipality do not include any social mechanisms, measures and programs to prevent the displacement of the low income groups.

These studies contribute to a great extent in our understanding of urban polices in Istanbul. However, the relationship between urban safety and urbanization in Istanbul has not yet been clarified sufficiently. This is because the theoretical designs of these studies are mostly the result of the influence of subjective perceptions of the permanent and transient environment, which may vary in its connection to objective reality. Other criticisms could be attributed to the fact that most studies are qualitative; and they do not give broad vision about crime, disorder, victimization and sense of security in Istanbul as a whole. Relying only on the official perspectives and figure must also be criticised. Because central and local authorities aim is to distract the reality of crime and disorder in order to create land values in Istanbul. In the official perspective, street crime is seen as an outgrowth of neighbourhood conditions. Some of these conditions are demographic, such as low levels of income, home ownership and residential stability.

The studies cited above mainly refer to official crime records and therefore their analysis and testing theories are limited and based on only official figures. Because of reporting and recording failures, official figures mislead the real extend of crime and disorder and lack of sense of security. All crimes committed are not recorded for different reasons and they are called "dark figure". Dark figure of crime is excluded in these studies and they fail to question the problems behind the official perspectives on crime and security issues in Istanbul. Mystifying street crime and underemphasizing white colour crime and corruption; official crime figures are also criticized on the grounds that they do not represent the reality. It may be questioned that relying on only official figures moves urban regeneration studies from reality to imaginary.

A final criticism in these studies lies in overgeneralization. Istanbul has unique neighbourhood environments in terms of crime, disorder, sense of security, community attachment and sense of belonging. Each area has specific problems in term of crime and disorder. For example, in Beyoğlu or other districts there are some areas where people from all social strata could share the same geographical environment. In these areas, sociospatial division is not as sharp as most studies above propose, and they fail to emphasis this important social reality in Istanbul.
How can we analyse the growth of new urban policies and strategies for urban transformation in the 2000s in Istanbul? What are the main elements of the urban transformation agenda and what are the political, social and economic motivations behind the change in urban policy approach in relation to urban transformation in the 2000s? What are the perspectives, significance and legitimizations linked by the local authorities to the issues of crime prevention and liability, which are among the main objectives of the urban renewal programs?

In order to discuss the above questions, this study will ground "defensible space" theory. The literature on spatial and architectural influences on crime has concentrated primarily on larger design aspects essentially building and street layout. Jacobs [11] first proposed the idea that urban planning could help renew community street life and thereby lower street crime. Many different kinds of physical marks and environmental measures have been linked to crime and deterrence [12]. Newman [12] expanded "defensible space" theory by suggesting that certain designs features, like barricades to block access and split public space into manageable zones, would strengthen a greater protection interest in the community. This, consequently, would lower crime and fear.

Defensible space is a system by which crime can be prevented by developing the opportunities for locals to control and defend their territory against crime, while together eradicating environmental aspects that bring criminals. Newman's theoretical framework suggests that defensible space is stimulated over three critical factors -territoriality, natural surveillance and image/ milieu - all of which really heavily on environmental arrangement in order to function effectively as crime prevention tools. The concept accommodates elements of a theory of crime as well as a set urban design principles. Newman states that defensible space is a model that can inhibit crime in residential environment. These environments might be specific building, projects or entire neighbourhood.

This article considers urbanization policies and practices in Istanbul, utilizing data gathered within the 'Istanbul Urban Safety Project' [13]. Work on the project included the identification of a range of models from the west in terms of urbanization policy and practice, which would seem to be different from those employed in Istanbul. The latter is apparently based on addressing issues concerning the fabric of deprived areas of Istanbul and regions where there is a high risk of earthquake, together with security fears. However, once administrative and political impacts are factored in, it would seem any aim of benefiting the whole community from urbanization turns into servicing the financial demands of an identifiable elite found in the highest echelons of society. Furthermore, another important problem is that community involvement in any urbanization development proposal is undervalued or overlooked completely; as if urbanization is a process which purely involves the physical 
refurbishment of buildings. It is actually a process which can tear apart the social fabric and social relationships; a rent that may result in the appearance of new socio-economic and socio-cultural problems.

This article evaluates relationships between views on security at neighbourhood level and across Istanbul in general based on responses to the survey questionnaire. At both levels, a relationship was determined between the ability of buildings to withstand earthquakes together with standards of cleanliness in the neighbourhood, and the presence of derelict property, street children and glue sniffers. Another important result showed the relationship between criminalization, together with the mystification of crime, and views on security. The effect of policies on criminalization and the mystification of crime were shown to be higher in the household survey than in its workplace equivalent.

\section{Method}

Data presented in this article was collected by the International Strategic Research Organization as part of the four year, 2008 2012, Istanbul Urban Safety Project. Quantitative and qualitative methods were used in the study. Quantitative methods included a large questionnaire survey administered to two samples: households and workplaces; together with analysis of secondary data. The qualitative dimension comprised semi-structured, openended interviews with a number of senior officials involved in urban safety in Istanbul. Almost 100 such interviews were carried out with Istanbul MPs, neighbourhood leaders, representatives of the Governor's office, senior personnel in Istanbul's citywide and district education authorities, officials from the police and judiciary, academics from Istanbul-based universities, heads of primary and secondary schools, local residents and representatives of the chambers of commerce and manufacture. This stage was seen as the establishment of relationships between a wide range of stakeholders in urban safety in Istanbul, together with the facilitation of dialogue and coordination between public and private organizations.

With regard to the questionnaire survey, the samples were prepared using baseline data from the Turkish Statistical Institute and it was planned to apply multi-level, stratified group techniques. However, it transpired that this would necessitate extremely large samples, the administration and management of which would have been beyond the scope of the project, hence the decision was taken to utilize probability sampling. Random sampling was deemed inappropriate for a city the size of Istanbul in which each district and neighbourhood may contain a wide range of social and physical conditions. In the event, baseline data led to a representative sample of 3140 households and 2000 workplaces.

Much time was devoted to questionnaire design prior to a pilot. Each question was subjected to repeated, detailed examination in the context of dependent, independent and control variables. The questionnaire was piloted in the following European districts of Istanbul: Bakırköy, Sarıyer, Beşiktaş; and on the Asian side of the city in Üsküdar, Ümraniye and Kadıköy. The piloting involved 200 questionnaires administered to 100 households and 100 workplaces. Following the pilot, 3140 questionnaires were distributed to households of which 2231 (71.1\%) were returned fully completed. The response rate for the 2000 workplace questionnaires was even higher with 1811 (80.6\%) being returned fully completed. Questionnaire data was analysed with SPSS software.

\section{Result}

On urban security, physical and social disorder, views from questionnaire responses reveal significant results. The household survey asked a question about the perceived effectiveness of local planning regulations in the context of security. Respondents were given a choice of responses and answered as follows: 'very effective' was chosen by $14.1 \%$; 'effective' by $39.8 \%$; 'ineffective' by $40.7 \%$; 'very ineffective' by $5.4 \%$. Another question on the issue of derelict property in the neighbourhood produced the responses: 'a very serious problem' chosen by $22 \%$; 'a serious problem' by $39.6 \%$; 'not a problem' by $29.1 \%$; 'not a serious problem' by $9.3 \%$.

Respondents to the questionnaire were also asked to rate the severity of certain problems in the neighbourhoods in which they lived. These problems included the issue of street children which was seen to be 'a very serious problem' by $19.0 \%$; 'a serious problem' by $50.0 \%$; 'not a problem' by $24.6 \%$; 'not a serious problem' by $6.4 \%$. Crime in the area in which they resided was perceived as 'a very serious problem' by $18.3 \%$; 'a serious problem' by $49.6 \%$; 'not a problem' by $25.4 \%$; 'not a serious problem' by $6.7 \%$. However, in response to the question 'What do you think about the problem of crime in Istanbul in general?' it was seen to be 'a very serious problem' by $65.1 \%$; 'a serious problem' by $32.9 \%$; 'not a problem' by $1.8 \%$; 'not a serious problem' by $0.2 \%$. As can be clearly seen from these results, crime was seen to be less of a problem at neighbourhood level than across the city as a whole. This difference could arise from policies on criminalization and the mystification of crime.

Another question was designed to measure the extent to which respondents felt safe in their own neighbourhoods. Answers were: 'I never feel safe' chosen by $2.3 \%$; 'I sometimes feel safe' by $27.7 \%$; 'I feel safe' by $63.6 \%$; 'I feel very safe' by $6.5 \%$. It should be borne in mind that such high levels of safety may well indicate that buildings in the neighbourhood concerned are in good physical condition and that strong social relationships are in existence.

$19.4 \%$ of respondents thought the biggest security problem for Istanbul as a whole was terrorist incidents, closely followed by $17.8 \%$ who chose public order as being most important. Close behind that group were the $17.3 \%$ for whom the most 
serious problem was glue sniffers and street children. Other problems chosen were: traffic by $11.9 \%$; migration by $11.5 \%$; mafia and gunfights by $10.8 \%$; community incidents by $10 \%$. At neighbourhood level it would seem the difference between perceptions of terrorism and those of glue sniffers and street children can be reduced to a mere $2 \%$.

For the householders, top of the list of issues which caused them anxiety was security. Results showed $28.9 \%$ chose this option. This was followed by the $25.1 \%$ who cited earthquake fear as their biggest worry.

Workplace respondents to the questionnaire produced similar results to the householders in answer to the question 'What do you think about the level of crime in Istanbul in general?' Choices from given responses were as follows: 'it is a very serious problem' was chosen by $62.5 \%$; 'it is a serious problem' by $32.6 \%$; 'not a problem' by $4.5 \%$; 'not a serious problem' by $0.4 \%$.

Workplace respondents chose public order $(20.7 \%)$ as the largest security problem in Istanbul. This was followed by $17.6 \%$ who chose traffic as the biggest problem and then terrorism chosen by $17.5 \%$; migration by $15.4 \%$; mafia and gunfights by $11.9 \%$; glue sniffers and street children by $10.1 \%$; community incidents by $5.8 \%$. As can be seen, there are differences between these results and those produced by the same question in the survey of households. The latter gave terrorism, public order and glue sniffers and street children as the top three security issues in that order; whereas the workplace respondents opted for public order, traffic and terrorism. It is also noticeable that the workplace respondents viewed the issue of glue sniffers and street children as less serious than did their household counterparts. In response to what workplace participants saw, from their own experience, as the biggest problems in the area in which they lived: $40.8 \%$ chose security, followed by $26.6 \%$ with fear of earthquakes.

Workplace respondents were also asked to comment on the problem of street vendors and responded as follows: 'a very serious problem' chosen by $13.5 \%$; 'a serious problem' by $39.3 \%$; 'not a problem' by $40.4 \%$; 'not a serious problem' by $6.8 \%$. In response to a similar enquiry regarding beggars: 'a very serious problem' was chosen by $19.3 \%$; 'a serious problem' by $40.6 \%$; 'not a problem' by $43.5 \%$; 'not a serious problem' by $6.6 \%$.

\section{Discussion}

In terms of urbanization and urban security in Istanbul, according to the results of qualitative research in this study, people actually resident in Istanbul with its convenient lifestyle and environmental conditions, do not themselves feel safe, which would seem to be a huge issue for the police alone to handle. Rapid urbanization combined with a wide range of social problems, together with actually living amongst neglected, vacant or abandoned buildings, are all factors contributing to the negativity of views on security. Furthermore, weaknesses in street lighting, police presence and city planning can be seen to have had an impact on the community's rising anxiety over security.

There is a need for approaches which include gathering the views of individuals and the community on what they see as threats to the physical and structural environment, classifying the data thus gathered, carrying out risk analysis and designing on the basis of all this, with security always in mind. As Newman [12] proposed, it should be noted that environmental design has been used as a successful preventative measure in many cities around the world, a concept which needs debate as to its application in Istanbul.

The community dimension plays an important role in urban security. Social and spatial segregation is an important characteristic of cities. Urban planning regulations must take into account social differences and structural differentiations. These regulations, whilst initially drafted by the authorities, must be presented to community groups and will show what form of relationship exists between the two sides [14]. Urban planning must be carried out in accordance with recognized physical and social characteristics, and urban social groupings should also be given consideration.

Urbanization should be defined as finding sustainable solution's to a city's economic, physical, social and environmental issues along with resolving problems peculiar to that city, the whole to be achieved in a context of integrated vision and action [15].

In the fieldwork, experts emphasized the importance of reducing the fear of earthquakes, and stressed that this could only be achieved when that fear was publicly acknowledged to exist. They also discussed the fact that TOKI's (Toplu Konut Idaresi) urban change programs are more often sited on publicly owned land rather than land which has housed shanty towns. However, in terms of earthquake risk, even private individuals building with permission on their own land cannot remove that risk entirely. The experts pointed out that urbanization has not been confined to private land, it has also taken place on the sites of former shanty towns, and there has even been significant construction on sites deemed at serious risk of earthquake.

A multi-dimensional approach to urbanization is essential. During field work for this study, we encountered the full gamut of views on which elements comprise urban change, including large numbers who mentioned the need for better architectural standards; for all work involving residents to be based on good, sound data; for better, higher quality education; that there be more and better opportunities for economic activity; that feelings of alienation be removed; public services become more effective; the crime rate drops. As can be seen from the aforementioned strategies, there are some positive aspects to safety in the context of urbanization. However, large socio-economic change such as wanting to return to a 'pure environment', or reduce 
crime and fear of crime, would just seem to lead to an increase in security problems. In regions where regeneration projects have been carried out, they have stated their aims to include: improved architectural standards; evaluation of population in the area; development leading to identification of weak points; provision of appropriate leisure facilities and social activities for local residents; creation of effective communication systems; addressing weaknesses in public services such as schools and hospitals; an increase in all forms of productivity.

Despite the fact that Turkey's shanty towns could be seen as high risk areas, if only in terms of physical structural safety, it has to be said that they are not the cause of any major anxiety. Within this study, meetings were held with academics that had carried out field work in shanty towns in the 1990s, without exception they painted a picture of neighbourhoods in which security had a strictly limited importance. One important result of our research is that public authorities and the academic community must accept that Turkey's shanty towns are very different to their equivalent ghettoes in the west, and this difference should be considered as part of any regeneration process.

As it was explained above 'defensible space' proposes that people need to feel a sense of ownership towards the space they occupy, and this can be nurtured through practical awareness raising [12]. Interestingly, residents in shanty towns display exactly this sense of ownership. It should be borne in mind that work has shown the necessity for consideration of regional characteristics and the ability to see things from the perspective of local residents. Despite the presence of so many risk factors, security problems did not emanate from the shanty towns, whereas overlooking social, cultural and economic issues inherent in any urban change project will lead to serious security problems. Academics with whom we met during the fieldwork emphasized the fact that moving people from a rundown district to a better area is hardly ever part of the solution to the problem. All urban change projects in general, and those involving rehousing in particular, must not just focus on physical refurbishment but must also aim to improve social, economic, demographic and cultural structures at the same time.

People living in a city should not feel themselves far removed from its life and culture, simply using the city as a place to live. One of the most important and necessary processes within social integration is that of city-dwellers finding common ground in shared values, opinions and activities. At the same time, it has to be agreed that relationships even with like-minded people, and certainly with extended family members and neighbours, can wax and wane and this has also to be accommodated within the fabric of any district. Indeed, for an individual to spend his/her entire life surrounded by like-minded people may not be such a good idea.

Data gathered from our field work showed that cities with an understanding of compatriotism do not undervalue its importance in the context of both social control and mutual support; it may also be an indicator of other issues. Academics who have an interest in this subject, all stated that whilst shanty towns may seem places of high risk with poor structural standards, it is clear that such areas are actually low risk in terms of security due to the strong sense of mutual support and other forms of social control. However, there can be negative aspects to basing your entire social life in the city on relationships with compatriots; city dwellers must identify with the city in which they live. For this change to take place requires highly detailed research followed by the implementation of appropriate strategies. Experts in the field believe this issue has not been treated seriously and will lead to significant increases in the crime rate over the years ahead. There has also been work to show that crime rates rise significantly in areas in which people are temporarily rehoused, whilst awaiting demolition and rebuild of their original homes.

Academics who have carried out research on this subject have stated that not enough attention is paid to the aftermath of an urban change initiative, when it could take up to ten years for people rehoused to establish relationships in their neighbourhood. People who move to a new neighbourhood within an urban change project leave behind the neighbours they may have known for years, and find themselves living in an apartment building surrounded by strangers with whom they must work out a way to live in harmony. Close links with neighbours which have lasted for years are all too often overlooked within urban change projects, and there are also inherent threats to be considered when people suddenly find themselves living in totally unfamiliar surroundings. Indeed, this situation is one of the sources of many problems within city life, a list headed by crime.

In terms of the effect of the physical fabric on security, experts involved in this study emphasised the fact that the physical condition of buildings has an effect on security and security fears, and they propose that urban change projects should pay greater attention to environmental design for security, and should involve people throughout the neighbourhood in design development. They also stressed the importance of design which gave opportunities for people to see and get to know one another. It would seem clear that individuals living in the same huge apartment buildings, where other residents remain strangers, feel themselves and their families to be unsafe. Furthermore, experts also mention the fact that in such circumstances people knowing each other is one element in crime prevention. Regeneration projects have been carried out which have resulted in apartment complexes with 300-400 people in each building, a total of 2000 or more in one complex, all forced to share many aspects of their lives. It should be borne in mind that such projects result in innate risks far higher than those present in shanty towns, where there are usually strong neighbour relationships.

\section{Conclusion}

This study greatly expands what is known about urbanization, urban regeneration, crime and urban policies in Istanbul. One of 
the significant of this study is that "household" and "work place" surveys were carried out separately in order to see the differences between responses from these different two categories. In terms of crime concern and sense of security, studies have not yet been clarified the differences between respondents from households and workplaces. Employing qualitative and quantitative methods, this study examines resident perceptions of territorial functioning and physical incivilities.

This study presents a more comprehensive and integrated framework for understanding specific features in urban security, physical and social disorder and urbanization. Thus, the theoretical framework is organized around two dimensions: 1-Neigbourhood level; 2. Istanbul as a whole. This classification shows the effects of the policies on criminalization and the mystification of crime, and it was found that crime was seen to be less of a problem at neighbourhood level than across Istanbul as a whole. Showing the difference between real problems and imaginary concerns about crime in Istanbul, this is one of the significant results of this study. This study is unique among others carried out in Istanbul and contributes to the existing literature by offering a new sociological perspective.

With a population of 15 million, Istanbul, Turkey's economic, cultural, and historical heart and its largest city experienced a dramatic economic, socio-political restructuring in the post1980 's with the neoliberal policies put in effect. The prospect of maximizing land prices and rentals became a considerable element reshaping the attitude of municipalities, construction firms and development agencies [16]. A Highly irregular, piecemeal, and speculative transformation of Istanbul has resulted in heightened social-spatial differentiations and fragmentation resulting from the changing economic, demographic and employment structures in the city. In the absence of the strategic plans and programs; the marked dynamics, ad hoc solutions of different actors, urban coalitions, informalities, political balances between different government layers have been shaping urban policies (Turel et al. 2006) [10]. Investing on urban land is regarded more beneficial than investing on industrial production and urban renewal proposals are justified mainly by fear of crime, disorder and crime prevention. Turkun [8] points out that people living in squatter housing areas were regarded "invaders". These areas were said to be the main cause of rising urban crime and political extremism. A new political elite consensus proposes that the immigrant squatter areas as well as the older ex-industrial areas inhabited by the urban poor urgently needed re-development. As a result, centralised urban policies and practices pave the way for excluding certain groups, mobilising the deprived groups and also putting pressure on the intellectuals and people with alternative political views. The criticisms of these parties are also regarded as oppositions to the overall project of economic development and as threats to their political power [17].

Contemporary urban governance is more than "the growing power of capital and the increasing inadequacy of liberal- democratic political structures as a means to check that power" (Purcell 2002) [17]. The state is the main actor, shaping the whole operation, trying to find ways to contain resistance or mobilisations against its urban agenda, using the urban property market as a machine for growth [17].

We have witnessed Istanbul, at the hands of the government, being reshaped and reorganized, with social values that have evolved over many years being removed and replaced with a new order. A whole new system of capital and production labour has been established. Whether the pretext is fear of earthquakes, criminalization or the need to deal with areas of deprivation, it would seem to lead to two basic conclusions. Firstly, urbanization policies are not matters for debate, being purely designed to ensure high rates of income; secondly, whole new templates for authority-order have been constructed (Tan 2013; İngin \& İslam 2013) [18-20].

It would seem that the administration in Istanbul classifies residential areas as 'at risk' without apparent consultation, and thus opens them up for regeneration and the attendant financial speculation. Financial gain from such urban change does not accrue to the residents, but rather to those who could be said to be already economically advantaged. Indeed, urban change programs are not carried out for the benefit of residents of the area concerned, instead the construction of luxury apartments, business districts, offices, hotels and shopping malls only benefits the already wealthy capital investors. The majority of urbanization projects force residents into a kind of limbo, in which they transfer their property ownership to capital investors cheaply and then have to move away. Istanbul heads the list of places in Turkey where decision makers claim to be working to create safer, more sustainable places to live, and where identifying exactly who is benefitting financially is practically impossible. It would seem that urbanization is trying to solve all the economic, social and environmental problems inherent in sustainable urban living at the same time and by pitting one against another [21].

The discussions above show that there is a relationship between city planning and political power [22]. According to Lefebvre the government and other powerful elites bring themselves into existence through space. To be able to attain and continue to hold sovereign powers the government, or leading elites, continually intervene spatially. To ensure the continuity of existing capitalist relationships of exploitation and domination, it is imperative that planning results in people of different classes and different ethnic identities becoming alienated from one another. Peoples' everyday experiences take place in a given space and when people are forced apart, they differentiate and become strangers to each other [22].

In Istanbul the government has implemented policies leading to decomposition and differentiation. In terms of urban decomposition, consider gated communities and shanty towns. Today this could not only be seen as spatial segregation, but 
could also qualify as a government management technique. When people find themselves experiencing or witnessing armed conflict in shared spaces, and capitalist exploitative relationships can continue, there must be planning. In Istanbul spatial segregation would seem to be very deep-rooted and there is a need to increase the number of shared spaces in which people of different social classes, ethnic and gender identities can meet and interact [2330].

\section{Funding}

This research was funded by USIDER.

\section{References}

1. Erder S (1997) Kentsel Gerilim. İstanbul: Uğur Mumcu Araștırmacı Gazetecilik Vakfi.

2. Erder S (1996) İstanbul'a Bir Kent Kondu: Ümraniye. İstanbul: İletişim.

3. Erman T (1998) Becoming "urban" or remaining "rural": the views of Turkish rural-to-urban migrants of the "integration" question. International Journal of Middle East Studies 30(4): 541-561.

4. Ișık O, Pınarcıoğlu M (2001) Nöbetleșe Yoksulluk, Sultanbeyli Örneği. İstanbul: İletişim.

5. Yalcintas HA, Kilinc G (2010) Evaluation of urban regeneration practice in Turkey in comparison to general framework for managing urban regeneration in developed countries. 14th International Planning History Society Conference.

6. Turkun A (2009) The Manifestations of Voluntary and Involuntary Migration in Turkish cities: from "spaces of hope" to "spaces of hopelessness". In: Sandhu RS, Sandhu J, Arora B (Eds.), Urban Poverty in Developing Countries: Issues and Strategies for Sustainable Cities. New Delhi: Bookwell, India, pp. 57-100.

7. Ozden P (2008) Looking at urban regeneration from the viewpoint of urban safety: Istanbul's crime areas. WIT Transactions on Ecology and the Environment 117: 579-590.

8. Turkun A (2011) Urban regeneration and hegemonic power relationships. International planning studies 16(1): 61-72.

9. Gökșin A, Müderrisoğlu B (2005) Urban regeneration: a comprehensive strategy for creating spaces for innovative economies. Urban Regeneration: A Comprehensive Strategy. 41st ISoCaRP Congress, İstanbul.

10. Sakızlığlu NB (2007) Impacts of Urban renewal Policies: The Case of Tarlabasi-Istanbul. Unpublished M.A. Thesis, The Graduate School of Social Sciences of Middle East Technical University, Ankara, Turkey.

11. Jacobs J (1992) The Death and Life of Great American Cities. New York: Vintage Books.

12. Newman O (1972) Defensible Space: Crime Prevention through Environmental Design. London: McMillan.
13. USAK (2012) İstanbul Kent Güvenliği. Ankara: USAK Yayınları.

14. Caldeira TPR (2000) Crime, Segregation, and Citizenship in Sao Paulo. Berkeley: University of California Press.

15. Roberts P, Sykes H (2000) Urban Regeneration, London: Sage.

16. Keyder C (2005) Globalization and social exclusion in Istanbul. International Journal of Urban and Regional Research 29(1): 124-134.

17. Eraydin A, Taşan-Kok T (2014) State response to contemporary urban movements in Turkey: A critical overview of state entrepreneurialism and authoritarian interventions. Antipode 46(1): 110-129.

18. Erkilet A (2013) Düzgün Aileler”, "Yeni Gelenler”e Karşı: Korku Siyaseti, Tehliyeler ve Kentsel Ayrışma. In: Çavdar A, Tan P (Eds.), İstanbul: Müstesna Şehrin, İstisna Hali, İstanbul: Sel Yayıncılık, pp. 127-146.

19. Yllmaz C (2013) Orta Sınıflar Üzerinden Düşünmek: İstanbul'da Orta Sınıfların Ajandasına Risk Yazmak. In: Çavdar A, Tan P (Eds.), İstanbul: Müstesna Şehrin, İstisna Hali, İstanbul: Sel Yayıncılık, pp. 99-123.

20. Balaban O (2013) Neoliberal yeniden yapılanmanın Türkiye kentselleşmesine bir değer armağanı: Kentsel dönüşümde güncelin gerisinde kalmak". In: Çavdar A, Tan P (Eds.), İstanbul: Müstesna Şehrin, İstisna Hali, İstanbul: Sel Yayıncılık, pp. 51-78.

21. Çavdar A, Tan P (2013) İstanbul: Müstesna Șehrin İstisna Hali. İstanbul: Sel Yayıncilık.

22. Lefebvre H (1976) Survival of Capitalism. London: Alison and Busby.

23. Eraydın A (2008) The Impact of Globalisation on Different Social Groups: Competitiveness, Social Cohesion and Spatial Segregation in Istanbul. Urban Studies 45(8): 1663-1691.

24. Genç FN (2008) Türkiye'de Kentsel Dönüşüm: Mevzuat ve Uygulamaların Genel Görünümü. Yönetim ve Ekonomi 15(1): 115-130.

25. Islam T (2005) Outside the Core: Gentrification in Istanbul. In: Atkinson R, Bridge G (Eds.), Gentrification in Global Context. London: Routledge, pp. 121-137.

26. Kuyucu T, Ünsal Ö (2010) Urban transformation as state-led property transfer: An analysis of two cases of urban renewal in Istanbul. Urban Studies 47(7): 1479-1499.

27. Șen B (2005) Soylulaștırma: Kentsel Mekanda Yeni bir Ayrıștrıma Biçimi. In: Kurtuluş H (Ed.), İstanbul'da Kentsel Ayrışma Istanbul: Bağlam Yayınları, pp. 127-160.

28. S Senyapılı T (2004) Charting the 'voyage'of squatter housing in urban spatial 'quadruped'. European Journal of Turkish Studies. Social Sciences on Contemporary Turkey (1).

29. Tasan-Kok T (2015) Analysing Path Dependence to Understand Divergence: Investigating Hybrid Neo-liberal Urban Transformation Processes in Turkey. European Planning Studies 23(11): 2184-2209.

30. Turkmen H (2014) Urban Renewal Projects and Dynamics of Contention in Istanbul: The Case of Fener-Balat-Ayvansaray and Suleymaniye. Phd Thesis, Cardiff University. 
This work is licensed under Creative Commons Attribution 4.0 License DOI: 10.19080/ASM.2020.05.555657

\section{Your next submission with Juniper Publishers} will reach you the below assets

- Quality Editorial service

- Swift Peer Review

- Reprints availability

- E-prints Service

- Manuscript Podcast for convenient understanding

- Global attainment for your research

- Manuscript accessibility in different formats

( Pdf, E-pub, Full Text, Audio)

- Unceasing customer service

Track the below URL for one-step submission https://juniperpublishers.com/online-submission.php 